\title{
Sex Education in the Eyes of Brazilian Public School Teachers
}

\author{
Denise Regina Quaresma da Silva ${ }^{1,2}$ \\ ${ }^{1}$ University Feevale, Novo Hamburgo, Brazil \\ ${ }^{2}$ Graduate Program in Education of the University Center La Salle-UNILASALLE, Canoas, Brazil \\ Email: denisequaresmadasilva@gmail.com
}

Received 16 June 2014; revised 20 July 2014; accepted 2 August 2014

Copyright (C) 2014 by author and Scientific Research Publishing Inc.

This work is licensed under the Creative Commons Attribution International License (CC BY). http://creativecommons.org/licenses/by/4.0/

(c) (i) Open Access

\begin{abstract}
This article presents the results of a research about the implementation of sex education in the public schools of Novo Hamburgo, Rio Grande do Sul, Brazil. Quantitative and qualitative methods were used and semi-structured interviews were conducted with 124 teachers from 56 public schools. The Discourse of the Collective Subject method was applied to analyse the interviews. The results show that sex education is not a crosscutting theme in schools, and that it is mostly dominated by the biomedical discourse. This means that non-heterosexual practices and identities are neglected and that representations of gender and sexuality that reproduce and legitimate gender disparity are accentuated.
\end{abstract}

\section{Keywords}

Sex Education, Schools, Sexuality, Gender, Brazil

\section{Introduction}

In Brazil, statistics about teenage pregnancy are a source of concern. The Brazilian Institute of Geography and Statistics (2009) came to the conclusion that there has been a small reduction of teenage pregnancy in the last 10 years. Nevertheless, a significant trend of rising numbers of pregnancies among teenagers aged between 10 and 14 has been observed.

"Youth and Sexuality", a Brazilian research supported by the UNESCO, brought to light an alarming finding: one in 10 students gets pregnant before the age of 15 (Garcia et al., 2004). It was also found that approximately $75.7 \%$ of teenage mothers drop out of school and that an average of 23 infants born to teenage mothers die per day, before they complete their first year of life (Unicef, 2011; Zurutuza, 2011).

Specifically in Novo Hamburgo, Rio Grande do Sul, Brazil, the infant mortality rate in 2010 was 35 per 
thousand live births and the proportion of newborns from teenage mothers accounted for $17 \%$ of all the births (Programa das Nações Unidas para o Desenvolvimento, 2009). This situation was very similar in 2007, when we interviewed teenage mothers and arrived at a shocking result: topics like sexuality, pregnancy and birth control were generally not talked about in the families of the teenage mothers (Quaresma, 2007).

Based on these results, we deemed it necessary to explore the implementation of sex education in the schools and proposed the project "Investigation of teenage pregnancy in municipal schools", sponsored by Feevale University since 2010. The principle objective of the project has been to characterise sex education in state primary schools in the city of Novo Hamburgo.

The results obtained on the project through semi-structured interviews with the teaching staff of 56 state primary schools are presented in this article. The methodological strategies used for the underlying quantitative and qualitative analyses are also presented.

Our aim is to show that, in the studied schools, sex education is not yet a crosscutting subject matter and that the biomedical discourse is dominating the arena. This means that non-heterosexual practices and identities are neglected, whereas gender-disparity-provoking representations of gender and sexuality are reproduced.

Sex education has been included in the National Curricular Parameters of the Brazilian Ministry of Education since 1996 as a crosscutting theme, which should be linked to the contents of each school subject in basic and secondary education schools. This article analyses the implementation of this government policy in the 56 basic education public schools of Novo Hamburgo, Rio Grande do Sul, Brazil, based on the statements of 124 teachers interviewed between 2010 and 2012. The results show that sex education is not a crosscutting theme in schools, and that it is mostly dominated by the biomedical discourse, focusing primarily on discussing reproductive organs, fertilisation, and contraceptive methods. This study also showed that the topics of sex education are only dealt with from a heterosexual point of view, thus denying other sexual identities. This signals the need to promote initiatives that question and overcome the strong connection between sex education and the dispositif of control, regulation and normalisation of bodies and their sexuality.

\section{Sex Education in Brazil}

The national Congress established, in December 1996, the Parâmetros Curriculares Nacionais (National Curriculum Parameters) and sex education was to become part of curricular as well as extracurricular activities in all Brazilian schools (Brasil, 1997).

A crosscutting approach to sex education aims to broaden the perspectives of current views on human sexuality. Therefore, topics such as respect for diversity, gender discrimination, parental responsibility and sexual and reproductive rights, among others, are included in the official guidelines for sex education. Nevertheless, after over 15 years, the confrontations between what can and cannot be said in schools set the pace at which the implementation of sex education is progressing.

During most of 2011, many Brazilian newspapers discussed the tensions related to sex education. These news did not only show the different discourses about sexuality circulating in society, but also revealed the unequal power relations behind the legitimisation or disapproval of these discourses. In a well-known Brazilian newspaper, the following communication was published: “After this Wednesday's meeting with delegates of the 'religious faction', the Federal Government has decided to suspend all materials dealing with the issue of homophobia which were being produced by the Ministry of Health and Education" (Zero Hora, 2011).

This piece of news refers to the project "School without Homophobia", an initiative of the Ministry of Health and Education that consists of developing a range of materials to help the teaching staff in their sex education activities. However, a variety of religious entities with a significant presence and influence in the National Congress oppose these proposals, which are meant to enforce the most basic human rights.

It is not the first time something like this has happened. At different moments in history, various institutions and social groups have been interested in, watchful of and anxious about what is said, done and transmitted with respect to sexuality in schools. This has been a discussion based on the proven efficiency of schools in controlling behaviours. Schools display a high efficiency in teaching what is good and bad, in stimulating certain behaviours and discouraging others, in legitimating certain identities and excluding others. This is why Foucault emphasises, in his analyses of disciplinary institutions, that schools form a micro-space of power that controls the bodies and the sexuality of pupils (Foucault, 2003).

This control over the body, gender and sexuality of pupils has a long history and has been exerted with arguments about moral, hygiene, health, epidemics, masturbation, contraception, paraphilia, teenage pregnancies, 
sexual and reproductive rights, prevention of sexually transmitted diseases, respect for sexual diversity, paternity, etc. All these arguments have served and still serve, with more or less vigour, to justify the need for sex education in schools. Each of these arguments activates, integrates or disdains different interpretative perspectives on sexuality and gender, which not only validate each specific argument, but also reflect practices and identities that are accordingly classified, organised, approved or disapproved, normalised or pathologized, criminalised or shielded by underscoring the need to respect diversity.

Along these lines, Ribeiro stresses that the Catholic Church has played a central role in the moral system reproduced in schools since the $16^{\text {th }}$ century. This form of sex education is significantly marked by a moral-religious discourse, which discriminated against non-heterosexual identities and practices in order to defend the heterosexual nuclear-family model and condemn abortion (Ribeiro, 2004). These questions are quite regularly (re)produced in other religious contexts frequently found in current practice of sex education (Jardim \& Bretas, 2006).

With the rise of the concept of an urban population, in the $19^{\text {th }}$ century, and the proliferation of sexually transmitted diseases, the need to instrumentalise policies and public actions emerged. As a consequence, a variety of sexual behaviours, such as masturbation, homosexual relationships and many others, were studied and classified as risky, deviant, paraphilic, abnormal, deficient or sexually perverted (Borrillo, 2010; Roudinesco, 2003).

Nowadays, sex education in Brazil is rather strongly influenced by this biomedical discourse, in which topics like prevention of sexually transmitted diseases and teenage pregnancies, hygiene and food as well as the biological changes in adolescence are emphasised (Sayão, 1997). Thus, this consists of a biomedical discourse, from which the issues of social construction of sexuality, sexual diversity and respect for the differences are missing or practically disregarded, which contradicts the all-embracing approach favoured by the National Curricular Parameters (Altmann, 2009).

This all-embracing perspective in sex education is currently labelled as politically correct. It is also linked with to the political demands of the lesbian, gay, bisexual, transsexual, intersexual, queer and feminist movements (LGBTIQ) for a sex education that does not encourage discrimination. It is important to underscore the fact that this view of sex education does not exclude the need to work with health and prevention, on the contrary; however, it questions health-promotion programs, policies and actions that exclude the non-heterosexual population and reinforce gender and sexuality attributions valued by the heteronormative system.

Currently, sex education in Brazil is a scenario where vigorous and unequal disputes for the preference of some topics and the disapproval of others, as well as the valorisation of some sexual and gender identities and the exclusion of others are taking place, and the teachers are at the centre of these contradictory demands. While some have decided to support one position, others prefer to stand in the middle ground. This must necessarily be taken into account when researching sex education practices in Brazil.

\section{Methodology}

We combined quantitative and qualitative methodologies, and our research project comprises the 56 state primary schools in the city of Novo Hamburgo, Rio Grande do Sul, Brazil. These schools have 8 grades and the age of pupils is generally between 6 and 14 years.

The instrument used to obtain the information was a semi-structured interview, which was applied to a non-probabilistic sample equivalent to $10 \%$ of the teaching staff, resulting in a total of 124 teachers interviewed. The criterion for selecting the teachers was their voluntary willingness to collaborate with the research. The process of interview and analysis took place between January 2010 and early 2012.

The choice of an open instrument like the interview was justified by the possibility of doing more extensive, profound and detailed analyses on the studied topic. This tool allows for a stronger understanding of the researched problem and increases the possibilities to explore the significances, concepts, definitions, characteristics, metaphors, symbols and beliefs around sex education (Minayo, 1994).

The semi-structured interview consisted of two types of questions: the so-called basic questions and the derived questions that spring from the answers given by the interviewees. After the data collection, the narratives were transcribed, revised and the initial units of analysis were redefined as follows: sex education as a crosscutting topic, school subjects where sex education is approached, which topics are tackled, and which conceptions about gender and sexuality are approached in sex education (see Appendix). 


\section{Results and Discussion}

Analysis of the interviews was carried out through the Técnica de Análise do Discurso do Sujeito Coletivo (Discourse Analysis Technique of the Collective Subject), which articulates collective declarations of opinions from individual accounts (Lefêvre \& Lefêvre, 2003). In this way, the collective subject talks as if it were an individual.

The DCS technique enabled us to discover the composition of the discourse, question by question. As a first step to the analysis, all the answers given to every question in the interview were identified. Then similar answers were grouped and the central idea that synthesises or reflects the core topic of that group of answers was extracted.

Finally, we obtained various core concepts from every question, which represented the possible collective discourses that had come up during the interviews. Each entity with similar answers configured a synthesised or collective discourse around a core concept. Interjections and reiterations were eliminated, so as to facilitate the understanding of the collective discourses. As a result, we obtained a sequential integration of the answers that circulated around this central idea, which is what is referred to as collective discourse.

The methodology was complemented by interpretative "translations" and processes made by the researcher about the collective discourse.

The Brazilian Ministry of Education and Culture proposes that sex education be approached as a crosscutting theme linked to the objectives, contents and activities of each schooling grade. In this respect, some questions gain importance: What do you understand by sex education? What does it mean to work sex education as a crosscutting theme? Which school subjects in which sex education is approached and which topics are tackled? Who is more in the focus of sex education, boys or girls?

The questions yielded the following results:

\subsection{Sex Education as a Crosscutting Theme}

As previously stated, the Brazilian Ministry of Education and Culture proposes that sex education be approached as a crosscutting theme linked to the objectives, contents and activities of each schooling grade. In this respect, and given their answers to the question what do syllabus parameters establish with respect to sex education? we were able to confirm that $100 \%$ of the teaching staff are aware of the crosscutting approach based on which sex education should be taught. Nevertheless, when the teaching staff were asked how is sex education tackled in schools? We could observe in Figure 1 that most of them interpreted crosscutting as meaning spontaneous, temporary and unplanned.

As understood by members of the teaching staff that subscribe to this view, sex education should not be a part of class planning; instead it should be a subject matter that comes up spontaneously and eventually. There is no diagnosis of the pupils’ problems or specific needs/request, nor is there planning regarding the appropriate time

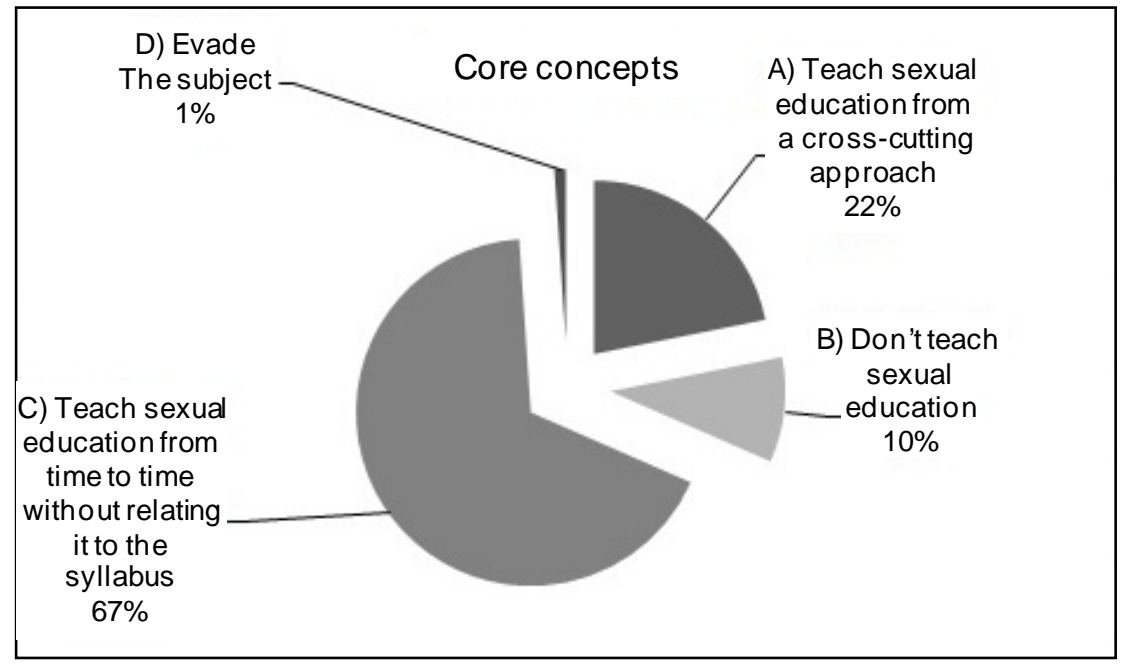

Figure 1. How is sex education taught in school? Source: Authors. 
to approach sex education and its connection/relation with the syllabus. A thorough analysis on which sex education viewpoint is transmitted, the values it promotes and how all this affect pupils are also left out from this framework.

As we see in Figure 1, "teach sex education from time to time without relating it to the syllabus" it's the concept that most teachers have (collective discourse) Let us examine it:

"There is no rule; there is no need to decide all right, now I'll teach sex education". The subject as institutionalised, each teacher will choose the right time to tackle sex education. You can't talk about things they are not curious about. A crosscutting approach means that you don't have to teach never planned a time to discuss it; we discuss it when a question or doubt comes up.

"I bring the subject up according to the pupil's interests. It's a thorny issue and one should let sleeping dogs lie. You shouldn't anticipate their questions or talk more than necessary. But their questions can't go unanswered, no matter what their age or grade is. With the youngest ones you tackles the issue if they ask, otherwise you don't. You cannot force it and you should always bear in mind their need to talk".

This framework shifts educational responsibility, allowing the teaching staff to contend that, once pupils do not ask, sex education is not talked about. Sex education appears only when elusive and evasive answers do not work in response to an explicit question and verbalised curiosity. This is the main sign of alert indicating that we should open the subject: teachers are pressured with questions, and remain cautious at all times. Doesn't this stance make childhood and adolescence even more vulnerable? What are we actually protecting them from?

Taking into account that the last assessment carried out by the Ministry of Health (1997-2007), which indicates that the city of Novo Hamburgo is among the 20 municipalities with the highest incidence of AIDS in Brazil, we can understand how inadequate sex education in schools impacts society. Nevertheless, we cannot regard statistics such as these as the only relevant factor.

Let us ponder some of the obstacles for implementing sex education as a crosscutting theme in the assessed schools. As we can infer from the collective discourse presented above, the fear of sparking an interest in sexuality among pupils is a major hindrance. This fear is based on the assumption that if sexuality is discussed, pupils will be incited to have sexual relations.

Research has also shown that this fear is closely related to family censorship. Also, as evidenced by the statements of various teachers, families are sometimes asked to approve the activities or materials used to teach sex education. One teacher stated: "whenever we wanted to discuss the issue, parents agreed. When the brochure about teenage health appeared, coordinators worked with pupils and, except for a few, most parents agreed".

On this aspect, we agree with Seffner:

"Primary school education is not just an extension of family education and the teacher is neither an aunt nor a second mom. The learning experience and social norms in school are defined by the social inclusion. Teachers should be seen as any other adult who in this case educates, and with whom pupils can chat about anything and in a different manner from the way they chat with their mother, father or a sibling. And most significantly, the teaching staff should be able to establish this dialogue taking into consideration public values and public ethics and not just their own personal beliefs" (Seffner, 2011: pp. 566-567).

Lack of training was another obstacle for further implementation of sex education. When exchanging ideas about their approach to gender and sexuality the teaching staff voiced that they had no training in this area and found it difficult to discuss those issues (Quaresma et al., 2012). Some pedagogic training programs in Brazil teach at least one course on gender and sexuality. This course is, for the most part, optional and has a general approach in the syllabi (Unbehaum et al., 2010). Subject matters such as sexuality, gender, sexual diversity, the body and prevention are scarcely approached. In turn, postgraduate courses in the area are still unable to reach to the large number of teachers who lack the theoretical and didactical resources needed for discussing gender and sexuality (Tamanini \& Santos, 2009).

\subsection{School Subjects in Which Sex Education Is Approached and Which Topics Are Tackled}

It is expected that a crosscutting approach to sex education will go beyond traditional approaches that place it within the sphere of Science. However, this approach is still deeply rooted. When asked in which school subject is sex education taught? Roughly more than half of the teaching staff mentioned Science, as shown in Table 1. 
Table 1. In which subject is sex education taught? Source: Authors.

\begin{tabular}{cc}
\hline Core concepts & Percentage (\%) \\
\hline A) There is no specific school subject for sex education & 30.84 \\
B) In Science & 57.01 \\
C) In Religion & 22.43 \\
D) In Physical Education & 13.08 \\
E) In Portuguese & 9.35 \\
\hline
\end{tabular}

With respect to the question which subject matters are approached/discussed/tackled in sex education? according to the collective discourse of main concept A (body and prevention are discussed):

"The Science teacher works with specific subject matters from which (s)he discusses body care, prevention and pregnancy. Science teachers do a great job at teaching the reproductive system, sexually transmitted diseases and other facts about teenage pregnancy. The youngest ones are taught 'how babies come to life', appropriate hygiene, and the differences between the male and female bodies. Last year we discussed sexual relations. We studied the human body and all its parts and then we discussed reproduction, pregnancy, and sexually transmitted diseases. Sex education is more explicit in biology, since it tackles health, diseases and reproductive organs. In science classes they study STDs and contraceptive methods”.

The biomedical discourse is the most valued and widespread in the scenario of schools where this research was carried out. Sexuality is discussed from a reproductive and scientific approach only, thus serving a religious viewpoint, which regards heterosexual relations as the norm and punishes the pursuit of pleasure. This evidences a paradox in the sex education practices of these schools - on the one hand, a permanent viewpoint that considers sexual relations and reproduction as one thing/as equal/as the same, and, on the other hand, attempts at preventing teenage pregnancy. To that respect, Altman points out:

"There seems to be a contradiction within the work carried out in the school. One of the objectives of sex education is avoiding teenage pregnancy [...] However, when sex is discussed, all the focus is precisely on fertilisation, pregnancy and motherhood” (Altmann, 2009: p. 191).

The subjects described by the teaching staff also evidence that in science class nothing is said about diversity. Within that framework, there are only heterosexual bodies, heterosexual relations, and heterosexual means of transmission. An exclusively heterosexual approach to sexual relations limits the access of an entire group of adolescents to information about prevention and non-heterosexual practices.

Over $85 \%$ of teenage girls referred to this collective discourse which favours a biomedical and preventive approach and a much smaller number mentioned other issues, such as gender violence, paedophilia, love and fidelity in sentimental relationships, parental responsibility, masturbation and abortion. As it can be observed in Figure 2, issues concerning pleasure, sexual and reproductive rights and diversity were not mentioned.

The legitimation of this biomedical discourse is also evidenced by the selection process, in which professionals are selected to talk in a conference. Some teachers described activities about sex education carried out in the school within the framework of institutional projects. Most of the speakers in these activities were medical doctors, gynaecologists or paediatricians.

\subsection{Conceptions about Gender and Sexuality in Sex Education}

Although the teachers' concepts of gender and sexuality appeared in almost all questions of the interview, a specific question about the topic was included to explore the matter in a more profound manner: Who is more in the focus of sex education, boys or girls? A little over $75 \%$ of the teachers answered that it is targeted at both, as shown in Figure 3.

Nevertheless, it can be seen that there are contradictions in the collective discourse of core idea A (Both):

"For everyone. For both. Girls do not do things alone. Sexuality is not only theirs, it is everybody's. It is as much for the boy as for the girl, but with the girl you have to deal with the issue of affection, while it is different with boys, because they give more attention to the physical issue. Both need to protect themselves 


\section{Core Concepts}

-A) Body and prevention are discussed

-B) Gender violence, paedophilia, love and fidelity in sentimental relationships, parental responsibility, masturbation and abortion are discussed.

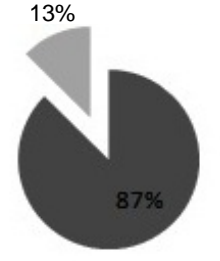

Figure 2. Which subject matters are approached in sex education? Source: Authors.

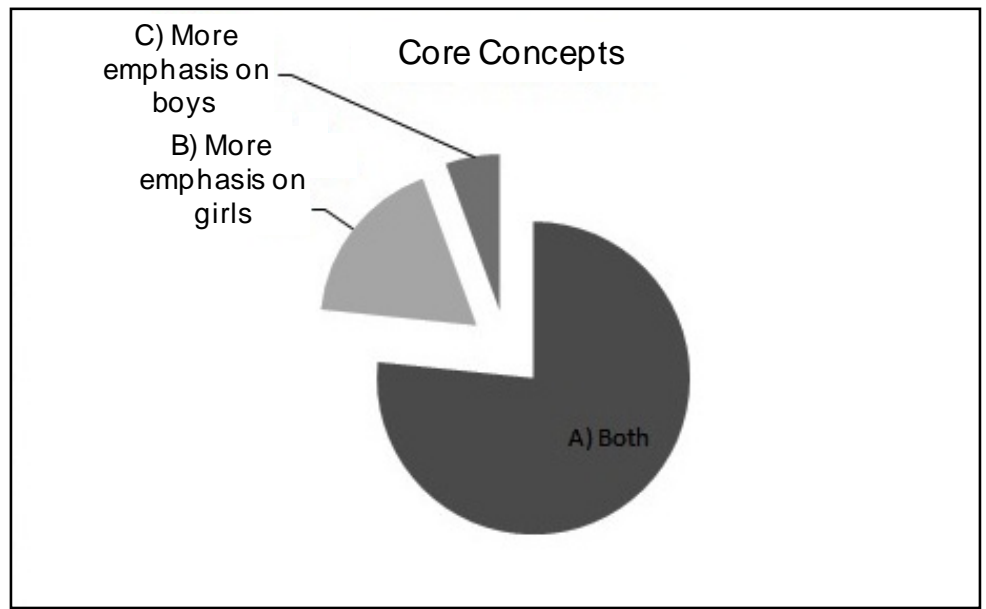

Figure 3. Who is more in the focus of sex education, boys or girls? Source: Authors.

and girls need to know how to avoid pregnancy. Both need to know about the topic, it affects the girls, but they don't get pregnant alone, it is together with the boys and the girls need to pay attention. I think that sex education should happen in the same way for both, but pregnancy also needs to be discussed directly with the girls".

We realised how the responsibility for pregnancy was repeatedly placed on the girls. The interviewees stated that it was necessary to work with the boys, but, ultimately, a hegemonic representation of femininity, which means that being a woman is being a mother, was legitimised. The model of scarifying maternity and distant or peripheral paternity happens to take responsibility away from the boys. Responsibility is not placed on teenage girls because of their uterus, but rather as a consequence of a social meaning that was constructed around this characteristic of the female body.

Let us take a look at how the collective discourse of core idea B (more emphasis on girls) seems to complement the collective discourse around idea A rather than contradict it:

"For the girls, because they are the ones who have to pay, they will be stuck with the child and the consequences are farther reaching for them. Sometimes we jokingly say that the students are on heat and/or in rut. Here we instruct the girls how they should behave, how they should dress and how they should wear adequate clothes. She is the one who will get pregnant, who will give birth, who will suffer and who will have this responsibility for life... and he as well, because he will be the father and will have to take care of the 
financial part. I always tell them, the ones who will have to stop going to parties, who will have to stop studying or stop working, are the girls".

In this collective discourse, when talking about the consequences of pregnancy and maternity, it is manifested how, based on the sociocultural interpretation and the female biological condition, different places and roles in society are defined for men and women: for women, there is housework and childcare and, for men, there is public life and financial support. Nevertheless, some signs of change with relation to the legitimate model of masculinity can be identified in the collective discourse C (more emphasis on boys):

"Mainly for the boys, especially here in the south where we have this sort of mandatory 'I am virile and a macho'. With the boys, because they don't take responsibility, get someone pregnant and then withdraw from their responsibility. With the boys, because the families are more used to controlling and protecting the girls, while the boys are free to do whatever they want. I think it is more for boys than for girls, because the girls have an idea, they will get pregnant, but the boys have no idea about being a father".

In this collective discourse there is a clear tendency to question the idea of distant paternity, which traditionally used to be a feature of hegemonic masculinity.

\section{Conclusions}

The way in which sex education is dealt with in the studied schools is significantly distant from its incorporation as crosscutting topic. Sex education is reduced to one-off, sporadic actions that generally arise as response to the curiosity that pupils manifest, and this poses a risk for childhood and adolescence. The assumptions about what it means to give sex education a crosscutting approach, the dread of talking about sexuality and the poor preparation of teachers are aspects that hinder the progress in the area.

The presented collective discourses also show that the prevalence of a biomedical discourse not only limits sex education to the field of Sciences, but also reduces the possibilities to foster a dialogue about other topics, such as pleasure, respect for diversity, and sexual and reproductive rights.

This study also showed that the topics of sex education are only dealt with from a heterosexual point of view, thus denying other sexual identities. This signals the need to promote initiatives that question and overcome the strong connection between sex education and the dispositif of control, regulation and normalisation of bodies and their sexuality.

\section{Acknowledgements}

This research is supported by the National Council for Scientific and Technological Development, CNPq, Brazil.

\section{References}

Altmann, H. (2009). Educação sexual em uma escola: da reprodução à prevenção. Cadernos de Pesquisa, 39, 175-200. http://www.scielo.br/pdf/cp/v39n136/a0939136.pdf

Brasil (1997). Ministério de Educação e Cultura. Parâmetros Curriculares Nacionais. Brasília: Ministério de Educação e Cultura.

Borrillo, D. (2010). Homofobia. História e crítica de um preconceito. Belo Horizonte: Autêntica.

Foucault, M. (2003). História da Sexualidade II: O uso dos prazeres (10th ed.). Rio de Janeiro: Graal.

García, M., Abramovay, M., \& Silva, L. B. (2004). Juventudes e sexualidade. Brasília: UNESCO.

The Brazilian Institute of Geography and Statistics (2009). Pesquisa Nacional de saúde do escolar. Rio de Janeiro. http://www.ibge.gov.br/home/estatistica /populacao/pense/pense.pdf

Jardim, D. P., \& Bretas, J. R. S. (2006). Orientação sexual na escola: a concepção dos professores de Jandira-SP. Revista Brasileira de Enfermagem, 59, 157-162. http://www.scielo.br/scielo.php?pid=S0034-71672006000200007\&script=sci_arttext.

Lefêvre, F., \& Lefêvre, A. M. C. (2003). O discurso do sujeito coletivo: um novo enfoque em pesquisa qualitativa. Caxias do Sul: Educs.

Minayo, M. C. (1994). Pesquisa social: Teoria, método e criatividade. Petrópolis: Vozes. 
Programa das Nações Unidas para o Desenvolvimento (2009). Informe de Acompanhamento Municipal dos Objetivos de Desenvolvimento do Milênio.

Quaresma da Silva, D. R. (2007). Mães-menininhas: A gravidez na adolescência. Ph.D. Thesis, Porto Alegre: Federal University of Rio Grande do Sul.

Quaresma da Silva, D. R., Sarmento, D. F., \& Fossatti, P. (2012). Género y sexualidad: ¿Qué dicen las profesoras de Educación Infantil de Canoas, Brasil? Education Policy Analysis Archives, 20. http://epaa.asu.edu/ojs/article/view/995

Ribeiro, P. R. M. (2004). Sexualidade e educação: Aproximações necessárias. São Paulo: Arte \& Ciência.

Roudinesco, E. (2003). A família em desordem. Jorge Zahar: Rio de Janeiro.

Sayão, Y. (1997). Orientação sexual na escola: Os territórios possíveis e necessários. In: A. J. Groppa (Ed.), Sexualidade na escola: Alternativas teóricas e práticas (pp. 107-118). São Paulo: Summus.

Tamanini, M., Santos, S. F. D., \& Sartor, G. E. B. (2009). Gênero, sexualidade e relações étnico-raciais: limites e desafios de um curso a distância. In: M. P. Grossi, \& M. C. D. S. Lago (Eds.), Práticas pedagógicas e emancipação: Gênero e diversidade na escola (pp. 67-92). Santa Catarina: Mulheres.

Unicef: Fundo das Nações Unidas para Infância (2011). O direito de ser adolescente: Oportunidade para reduzir vulnerabilidades e superar desigualdades. Brasília: UNICEF. http://www.unicef.org/brazil/pt/br sabrep11.pdf

Unbehaum, S., Cavasin, S., \& Gava, T. (2010). Gênero e sexualidade nos curriculos de pedagogia. In: Anais: Seminário Internacional Fazendo Gênero 9 (pp. 1-10). Florianópolis: Federal University of Santa Catarina.

Zero, H. (2011). Após pressão de religiosos, Dilma suspende produção de kit anti-homofobia. http://zerohora.clicrbs.com.br/rs/geral/noticia/2011/05/apos-pressao-de-religiosos-dilma-suspende-producao-de-kit-anti-ho mofobia-3323528.html

Zurutuza, A. (2011). A cada mês, 4 crianças filhas de mães adolescentes morrem antes do 1 ano. Correio do Estado. 


\section{Appendix}

Topics of analysis, interview questions and core concepts that emerged:

\begin{tabular}{|c|c|c|}
\hline Categories of analysis & Guiding questions & $\begin{array}{l}\text { Core concepts that emerged in similar or equivalent } \\
\text { answers }\end{array}$ \\
\hline \multirow{5}{*}{ Sex education as crosscutting theme } & $\begin{array}{l}\text { What do syllabus parameters } \\
\text { establish with respect to sex } \\
\text { education? }\end{array}$ & It is a crosscutting theme \\
\hline & \multirow{4}{*}{$\begin{array}{l}\text { How is sex education taught in } \\
\text { school? }\end{array}$} & A) Teach sex education from a crosscutting approach \\
\hline & & B) Don't teach sex education \\
\hline & & $\begin{array}{l}\text { C) Teach sex education from time to time without } \\
\text { relating it to the syllabus }\end{array}$ \\
\hline & & D) Evade the subject \\
\hline \multirow{7}{*}{$\begin{array}{l}\text { School subjects where sex education is } \\
\text { approached and which topics are } \\
\text { tackled }\end{array}$} & \multirow{6}{*}{$\begin{array}{l}\text { In which subject is sex education } \\
\text { taught? }\end{array}$} & A) There is no specific subject for sex education \\
\hline & & B) In science \\
\hline & & C) In Religion \\
\hline & & D) In Physical Education \\
\hline & & E) In Portuguese \\
\hline & & A) Body and prevention are discussed \\
\hline & $\begin{array}{l}\text { Which subject matters are } \\
\text { approached in sex education? }\end{array}$ & $\begin{array}{l}\text { B) Gender, violence, paedophilia, love and fidelity in } \\
\text { sentimental relationships, masturbation and abortion } \\
\text { are discussed. }\end{array}$ \\
\hline \multirow{3}{*}{$\begin{array}{l}\text { Conceptions about gender and } \\
\text { sexuality in sex education }\end{array}$} & \multirow{3}{*}{$\begin{array}{l}\text { Who is more in the focus of sex } \\
\text { education, boys or girls? }\end{array}$} & A) Both \\
\hline & & B) More emphasis on girls \\
\hline & & C) More emphasis on boys \\
\hline
\end{tabular}


Scientific Research Publishing (SCIRP) is one of the largest Open Access journal publishers. It is currently publishing more than 200 open access, online, peer-reviewed journals covering a wide range of academic disciplines. SCIRP serves the worldwide academic communities and contributes to the progress and application of science with its publication.

Other selected journals from SCIRP are listed as below. Submit your manuscript to us via either submit@scirp.org or Online Submission Portal.
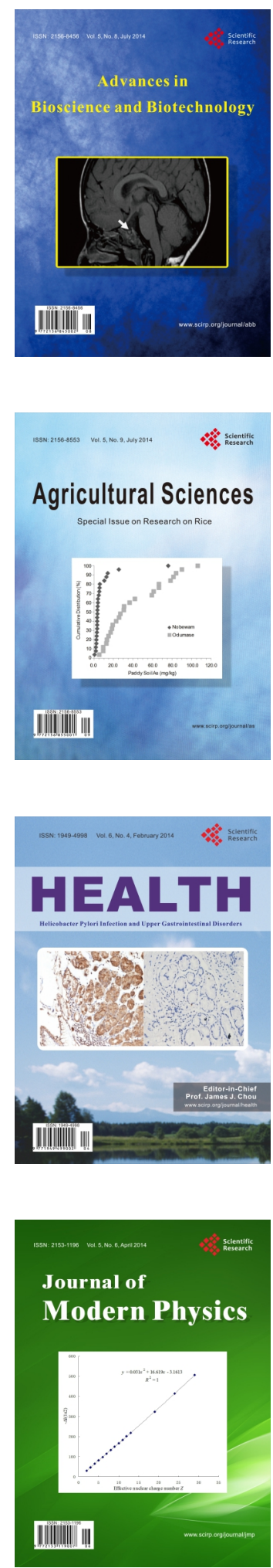
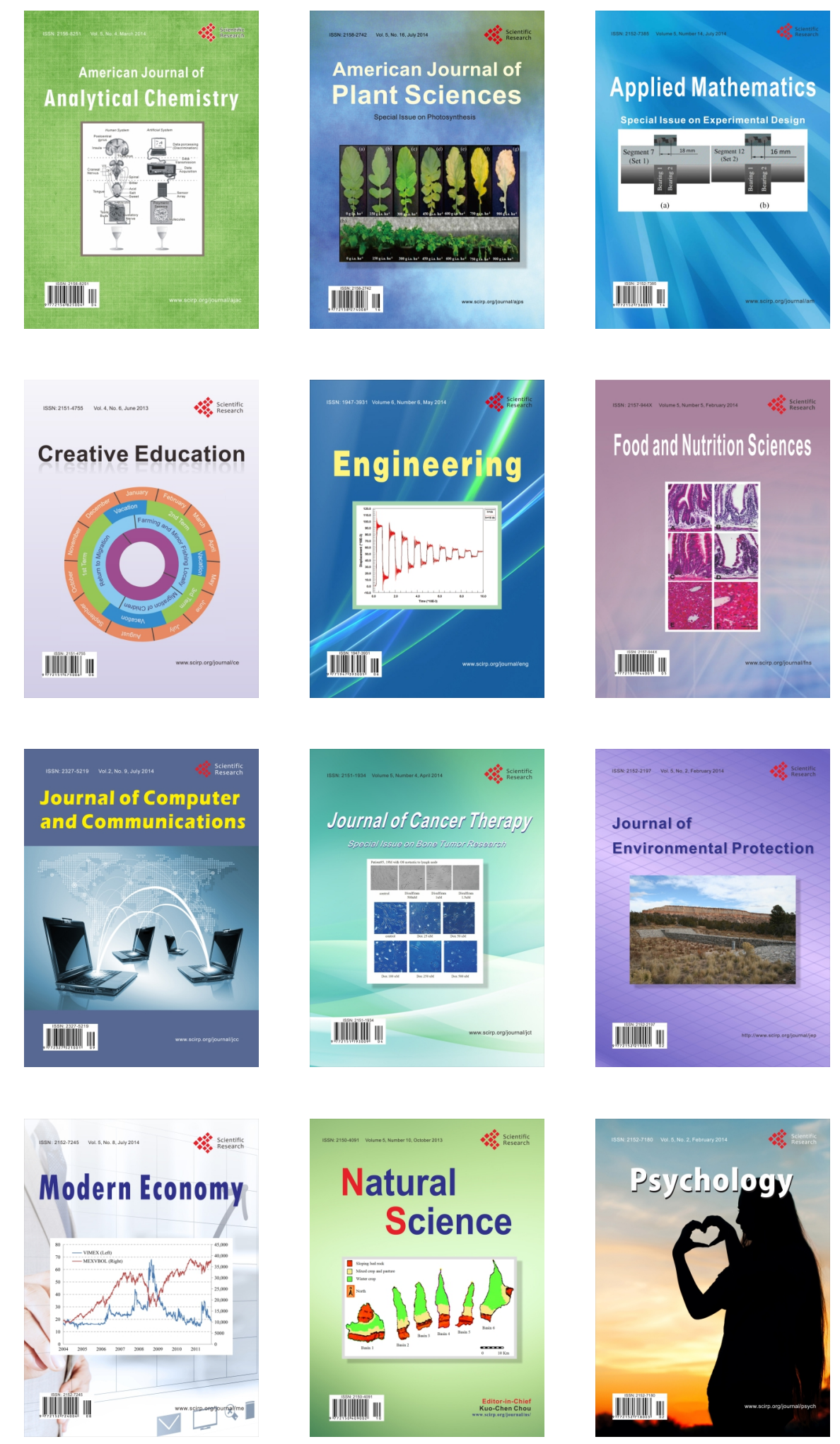